\title{
Evolutional Characteristics of Debris Flow in the Siwalik Hills of Nepal
}

\author{
${\text { Bharat Prasad Bhandari }{ }^{*}(\mathbb{D}, \text {, Subodh Dhakal }}^{2}$ \\ ${ }^{1}$ Central Department of Environment Science, Tribhuvan University, Kirtipur, Nepal \\ ${ }^{2}$ Department of Geology, Tri-Chandra Multiple Campus, Tribhuvan University, Kathmandu, Nepal \\ Email: ^bbhandari@cdes.edu.np
}

How to cite this paper: Bhandari, B.P. and Dhakal, S. (2019) Evolutional Characteristics of Debris Flow in the Siwalik Hills of Nepal. International Journal of Geosciences, 10, 1049-1067.

https://doi.org/10.4236/ijg.2019.1012060

Received: November 2, 2019

Accepted: December 3, 2019

Published: December 6, 2019

Copyright $\odot 2019$ by author(s) and Scientific Research Publishing Inc. This work is licensed under the Creative Commons Attribution International License (CC BY 4.0).

http://creativecommons.org/licenses/by/4.0/

\begin{abstract}
As a youngest Mountain of the world, Siwalik region of Nepal is facing several mass movements like landslide and debris flow in monsoon period every year. Debris flow is very common in the steep slope of weak and fragile sedimentary rocks. This paper used remote sensing data and GIS to evaluate evolutional characteristics of debris flow hazard in the Siwalik hill of Babai watershed based on the geological, topographical and hydrological factors. All together 101 debris flow polygons were made by using Google Earth and by field verification. Digital Elevation Model (DEM) was used to analyze debris flow distribution and topographical features. Lithostratigraphy was studied to evaluate geological characters and rainfall data was used to evaluate hydrological character. Average slope for debris flow evolution in Lower, Middle and Upper Siwalik is $34^{\circ}, 50^{\circ}$ and $30^{\circ}$ respectively. The average 24 hours rainfall to occur debris flow is found $160.67 \mathrm{~mm}$. The area and length of debris flow channel are significantly different in three geological formations. The temporal distribution of debris flow from 2001 to 2018 shows that the trend of debris flow generation is higher in Middle Siwalik rocks with slope greater than $30^{\circ}$. Three major sources of debris flows were evaluated namely slide induced debris flow, fall induced debris flow and erosion induced debris flow where the slide induced debris flow is predominant. This study can be better source to understand the general mechanism of debris flow generation to the policy makers for reducing the future impact of debris flow in the overall Siwalik zone of Nepal.
\end{abstract}

\section{Keywords}

Debris Flow, GIS, Siwaliks, Topography

\section{Introduction}

A debris flow is the rapid down slope movement of well graded granular solids 
mixed with water, occurring in the steep channels of mountain environments [1], [2], [3] characterized by high velocity [4] and sudden evolution. The debris flow differs from slow-moving landslides and controlled by the geological-structural setting of the slope [5]. The initiation of debris flow is related to the slope of the source areas; a typical value is between $27^{\circ}$ and $38^{\circ}$ [6], [7], [8]. In addition, there is a specified curvature in topography in debris flow source area. Due to those regions, the debris flow erodes the heavy materials from the hill slope or gulley and deposits a huge amount of sediments. During that mechanism, it destroys properties and life every year in the mountainous region of Nepal during rainy season. The primary triggering factor for debris flow generation is intense rainfall which leads to reduced effective stress and thus slope instability. Every recorded debris flow event in Nepal has coincided with intense or long duration rainfall.

The Himalaya is geologically very young and tectonically most unstable mountain landscapes of the world [9]. These landscapes are vulnerable to various natural hazards, including landslides, debris flows and soil erosion primarily triggered by extensive rainfall of monsoon [10]. Debris flows are major landslide problems in Nepal which are initiated at the gullies of hill tops in small catchments and flow down with the high velocity [11]. The Siwalik region of Nepal has been suffering by landslides and debris flows since the past. The Siwalik consists of loose and fragile sedimentary rocks and quaternary fluvial deposit erodes out with a large amount of sediments and transported in the time of intense rainfall. Most of the Siwalik hill consists of steep slope morphology and mobilizes a lot of loose sediments under the influence of surface runoff [12]. The debris flows triggered by heavy rainfall in 2016 and 2018 have received much attention in the west Siwalik zone of Nepal. The large scale debris flow in different events of 2016 and 2018 caused large flooding and damming in the western Terai region of Nepal. In Nepal, many people are living under the hills and mountain with agricultural practices. The peoples are unknown about the potential area for landslide and debris flow. Due to sudden and unexpectedly generated mechanism, the debris flow often causes life and properties loss in the hilly and Himalayan region of Nepal. To identify the mechanism and generation of debris flow in the hilly and mountainous region is very important task for sustainable life and development in the country like Nepal. Finding the topographical, geological and hydrological factors for the evolution of debris flow in the Siwalik hills is the main purpose of this study.

The sediments for the debris flow may be generated from landslide and erosion on the slope [13]. Scientific investigation and qualitative discussion of the definition of debris flow is very important task for present. [14] studied about the role of debris flow on the change of $10 \mathrm{Be}$ concentration in the Seti River of Nepal. [15] studied the landslide and debris flow of the Madi River of Nepal and they reported that heavy rainfall is the cause of large landslide and debris flow in the Nepal Himalaya. [16] studied the debris flow of Bhotekoshi River valley of Nepal. [17] studied about the debris flood of Seti River of Nepal and elaborated 
the mechanism of glacial lake outburst flood (GLOF) and resulting debris flood in the glacial lake originated River. [13] reported that the probability of debris flow to occur increases with increase of topographic factors in the thrust zone at weak sedimentary terrain. They concluded that the topographical and geological factors are mainly responsible for gully-type debris flow in the Siwalik region. There is limitation of study of debris flow in the study area mostly in Siwalik region. This study aims to fulfill the data gap of study area related to debris flow in terms of topographical, geological and hydrological factors.

Based on the above considerations, the paper aims to identify the status and mechanism of debris flow evolution in the catchment scale of Siwalik hill of Nepal. The results will give the characteristics of debris flow and information of debris flow evolution in the Babai River watershed of Siwalik hills of Nepal. This work is very important for present and future to understand the generation and mechanism of debris flow in Siwalik hills though it is in catchment scale but it will be the reference and basement for the further study about landslide and debris flow. This study may be useful to compare the result with other global sedimentary terrains.

\section{Materials and Methods}

\subsection{Study Area}

The study area lies in the Babai Khola section of Siwalik hill of Nepal. It covers three districts of Mid-Western Development Region of Nepal namely Dang, Salyan and Bardiya (Figure 1(A) \& Figure 1(B)). The Babai River is east-west trending river originated from Siwalik and located between $27^{\circ} 57^{\prime} 59.03^{\prime \prime N}$, $82^{\circ} 33^{\prime} 42.80^{\prime \prime} \mathrm{E}$ at east, $28^{\circ} 28^{\prime} 30.14^{\prime \prime} \mathrm{N}, 81^{\circ} 28^{\prime} 30.14^{\prime \prime} \mathrm{E}$ at west, $28^{\circ} 12^{\prime} 47.90^{\prime \prime} \mathrm{N}$, $82^{\circ} 15^{\prime} 46.08^{\prime \prime} \mathrm{N}$ at north and $28^{\circ} 01^{\prime} 03.89^{\prime \prime} \mathrm{N}, 82^{\circ} 12^{\prime} 39.61^{\prime \prime E}$ at south (Figure 1(A) \& Figure 1(B)). Total area covered by Babai catchment in Siwalik zone is 1700 $\mathrm{km}^{2}$ but the study area covered only $1157 \mathrm{~km}^{2}$ because Quaternary deposit of Dun valley is excluded in this study.

The Siwalik in the study area has altitudes ranging from $300 \mathrm{~m}$ to $1500 \mathrm{~m}$ and exhibits a very rugged topography with highly dissected gullies and steep slopes. Most of the mountain ridges in the study area extend in the east-west direction, parallel to the main geological structures. The landforms of the study area are mainly controlled by the tectonic processes and subordinately by mass wasting and weathering. The erosional landforms predominate over the depositional ones. There are rugged hills, numerous deep gorges, steep slopes, cliffs, and active gullies representing the erosional landforms, whereas river terraces, alluvial fans, and talus cones are the examples of depositional landforms. The hill slopes are drained by number of small and medium stream. Most of the stream are dry and flow only during and after the heavy rainfall. Many places of hills are affected by deep erosion mostly caused by ephemeral stream. The major River systems in the study area are: Babai Khola, Gwar Khola, Baula Khola, Patu Khola, Sarada Khola, Malai Khola and Tui Khola respectively. Drainage density is higher toward North-East and lower towards South-West. 


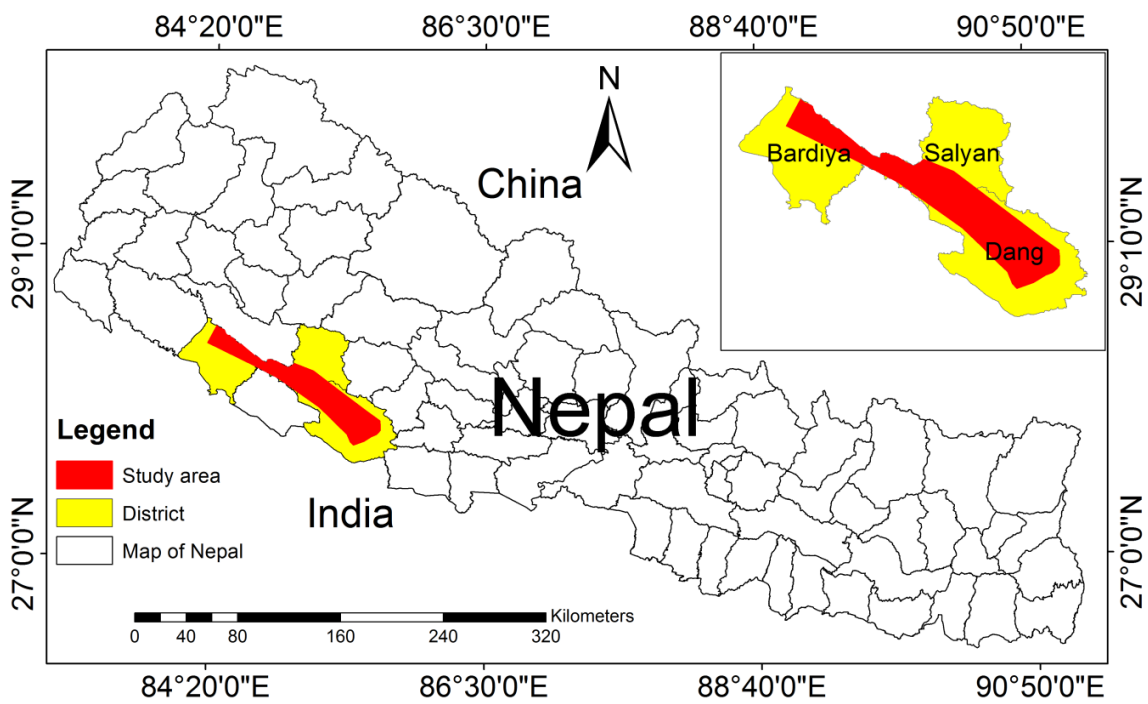

(A)

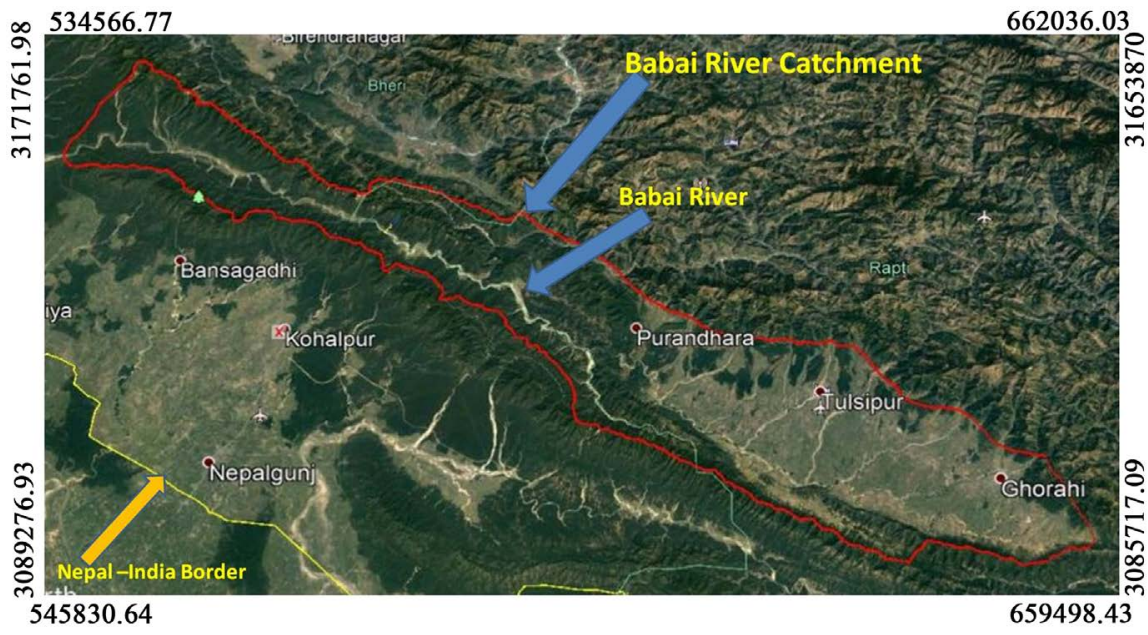

(B)

Figure 1. (A) Location map of Babai watershed of Siwalik zone of Nepal; (B) Location map of Babai watershed of Siwalik zone of Nepal, in Google Earth.

The climate of study area is sub tropical. The winter is very cold and summer is very hot. The rainfall is heavy and occasionally intense during rainy season. The average annual rainfall over the period 1986-2017 is in the range of 1400 $3000 \mathrm{~mm}$. More than 80 percent of rainfall occurs in rainy season.

\subsection{Geological Setting}

The bed rock geology of study area is dominated by younger (Neogene) sedimentary rocks. Rocks of study area are divided into three formations [18]. From bottom to top they are Lower Siwalik, Middle Siwalik and Upper Siwalik respectively (Figure 2). The main compositions of Lower Siwalks are interbedded fine to very fine grained grey-green sandstone and red-purple brown mudstone. Mudstone bed is medium to thickly bedded, highly fractured and highly weathered. Sandstone bed is of thinly bedded and spheroidically weathered [18]. The 


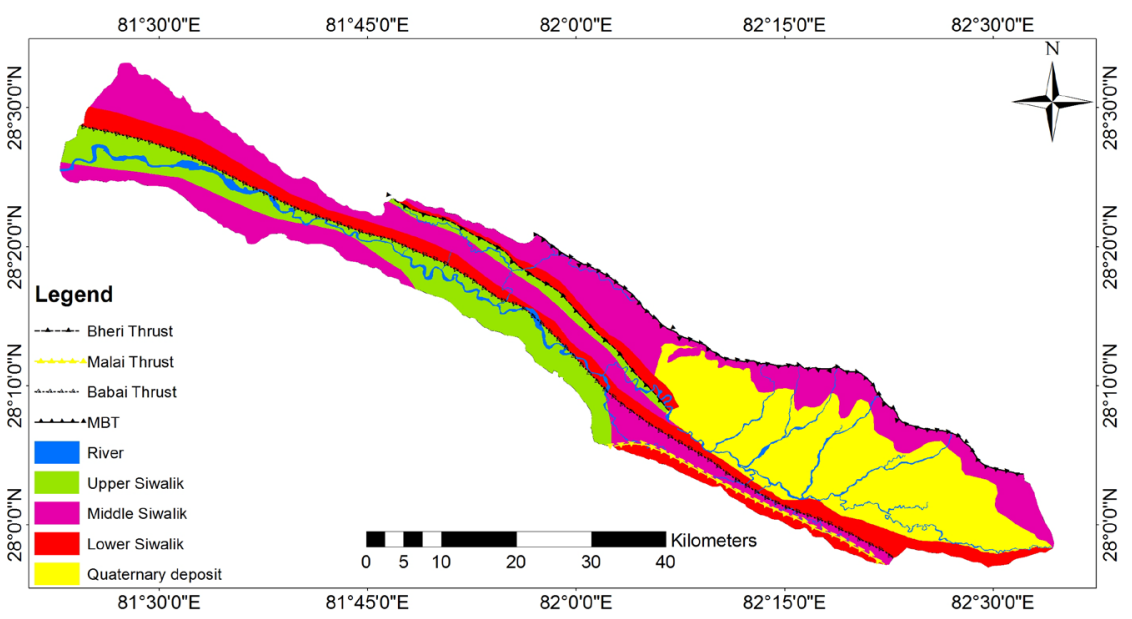

Figure 2. Stratigraphical map of Babai River watershed of Siwalik zone, Nepal (Source: Field visit 2018).

minerals present in sandstone are quartz, muscovite, biotite and feldspar. Lower Siwalik composed of siltstone, red shale facies with minor sandstone and pseudo conglomerate [19]. Middle Siwalik consists of medium to coarse grained thickly bedded salt and pepper as well as pebbly sandstone and variegated mudstone. Sandstone beds are massive, less compact and weathered due to poor intergranular bonding [18]. The sandstone of Middle Siwalik consists of quartz, feldspar, muscovite and biotite. The bed of sandstone is thicker than mudstone. The thickness of sandstone bed varies from $30 \mathrm{~cm}$ to $3.4 \mathrm{~m}$ whereas thickness of mudstone bed varies from $7 \mathrm{~cm}$ to $52 \mathrm{~cm}$. Upper Siwalik consists of cobble and pebble bearing conglomerate interbedded with yellow to brown mudstone. The cementing material of conglomerate is calcite and mostly clay. The size of clast in conglomerate varies from $5 \mathrm{~mm}$ to $10 \mathrm{~cm}$. Most of the flat lying area is covered by superficial quaternary deposits.

Study area consists of four major thrusts namely Main Central Thrust (MBT), Babai Thrust (BT), Bheri Thrust (BhT) and Malai Thrust (MT). Main Boundary Thrust separates the study area with Lesser Himalaya. Babai Thrust and Bheri Thrust are considered as active thrust of the study area.

In hilly terrain, colluviums including debris-flow and other slope debris deposits, mostly of late-quaternary period. Colluviums occur as relatively thick deposits filling drainage courses. However, there are deposits which are considerably thinner and of greater areal extent on some hill slopes in the study area. The colluviums derived from erosion and landslide typically consists of sub angular cobbles and boulders of sandstone and mudstone with some conglomeratic fragments. Huge amount of alluvial deposits occur in river terrace and valley fill.

\subsection{Methods}

\section{Debris flow inventory}

The debris flow inventory map was prepared by using polygon based method in the satellite images. The time series Google earth images and images of Alaska 
Satellite facility were used for inventory. The polygons were drawn from scar to the fan by following flow channel. The KML file of inventory was obtained the Q-GIS, freely available software. The total area covered by flow, length of flow and perimeter of flow were identified from GIS. The prepared inventory was finalized by intense field study. The major sources of debris flow, nature of flow, types of movements were identified in the field study. The spatial and temporal inventory was prepared from 2001 to 2018.

\section{Geological mapping}

Geological mapping was carried out in the field. Topo-sheets of 1:25,000 prepared by department of survey, Nepal were used to prepared geological map. The strike, dip and dip amount of bed rock was measured in the field and plotted in the Topo map. The study area is divided in the three formations on the basis of Lithology. After draft mapping, the topo map was scanned and digitized in the GIS. The digitized map was re-drawn and finally prepared the Geological map.

\section{Topographical factors}

Topographic map at scale 1:25,000 provided was obtained from the department of survey, government of Nepal. The digital elevation model (DEM) with $30 \mathrm{~m}$ of spatial resolution was obtained from contour map provided by department of survey, Government of Nepal. The slope, aspect and elevation were identified from DEM.

\section{Hydrological factor}

Rainfall data of 2001 to 2018 was taken from Department of Hydrology and Meteorology, Government of Nepal. Maximum 24 hours rainfall and total annual rainfall was obtained.

\section{Field work}

In this work, researcher spent most of the time in the field and did evaluation about different causative factors for debris flow evolution. Elevation, slope angle and average depth of gulley were measured in the field. The debris materials were observed and assumptions were made. The types of flow, origin of flow and evolution mechanism were studied in the field.

\section{Data management}

The data were arranged and evaluated in the excel sheet. R software was used to analyze the data. The area and length of debris flow were evaluated with geological formations. The frequency and cumulative frequency of debris flow in different geological units were evaluated in MS Excel and R software. The different of area and length of debris flow and slope of debris flow origin were identified in different geological formations. One way analysis (One way ANOVA) is used to test the differences of debris flow among the three geological formations; box plots are prepared to visualize the information.

On the basis of field data, three types of debris flow sources are categorized namely slide, flow and fall. On the basis of source, three types of debris flow are categorized namely slide induced debris flow, fall induced debris flow and erosion induced debris flow. 


\section{Results}

\subsection{Inventory of Debris Flow}

All together 101 debris flow events were studied in the field (Figure 3). The total area occupied by debris flow is $19.249 \mathrm{~km}^{2}$ among $1157 \mathrm{~km}^{2}$ total study area. The debris flows are found to be evolved after the material deposited by landslide at the hill slope and continuous erosion of slope materials by rainy water. The origin of debris flows are classified into three groups namely fall, slide and erosion. The slide is found higher in number among the other types of movement. Slides are found to be the main source of debris flow (68.3\%) followed by erosion $(22.7 \%)$ and fall (9\%).

\subsection{Debris Flow Distribution}

\subsubsection{Geological Distribution}

After the preparation of inventory map, analysis of landslide and debris flow distribution, characteristics and morphology of area, was performed. Among all the debris flows, $78 \%$ of the debris flows are identified as gulley type and rest of the flows are hill slope debris flow. However, the area of debris flow events is found to vary according to the geological formations. In the Lower Siwalik, 10 debris flows have area between 0.1 to $1 \mathrm{~km}^{2}$ and 21 flows have area greater than $1 \mathrm{~km}^{2}$. Similarly in Middle Siwalik, 18 debris flows have area between 0.1 to 1 $\mathrm{km}^{2}$ and 26 debris flows have area greater than $1 \mathrm{~km}^{2}$. In Upper Siwalik, only 15 debris flow has area greater than $0.1 \mathrm{~km}^{2}$. The larger sized and the longest debris flows are found in the Middle Siwalik (Figure 4). [13] concluded that the number of landslides is higher in Middle Siwalik which has higher probability to occur debris flow. The total number and total area of debris flow in different geological formations of Siwalik zone are shown in Table 1.

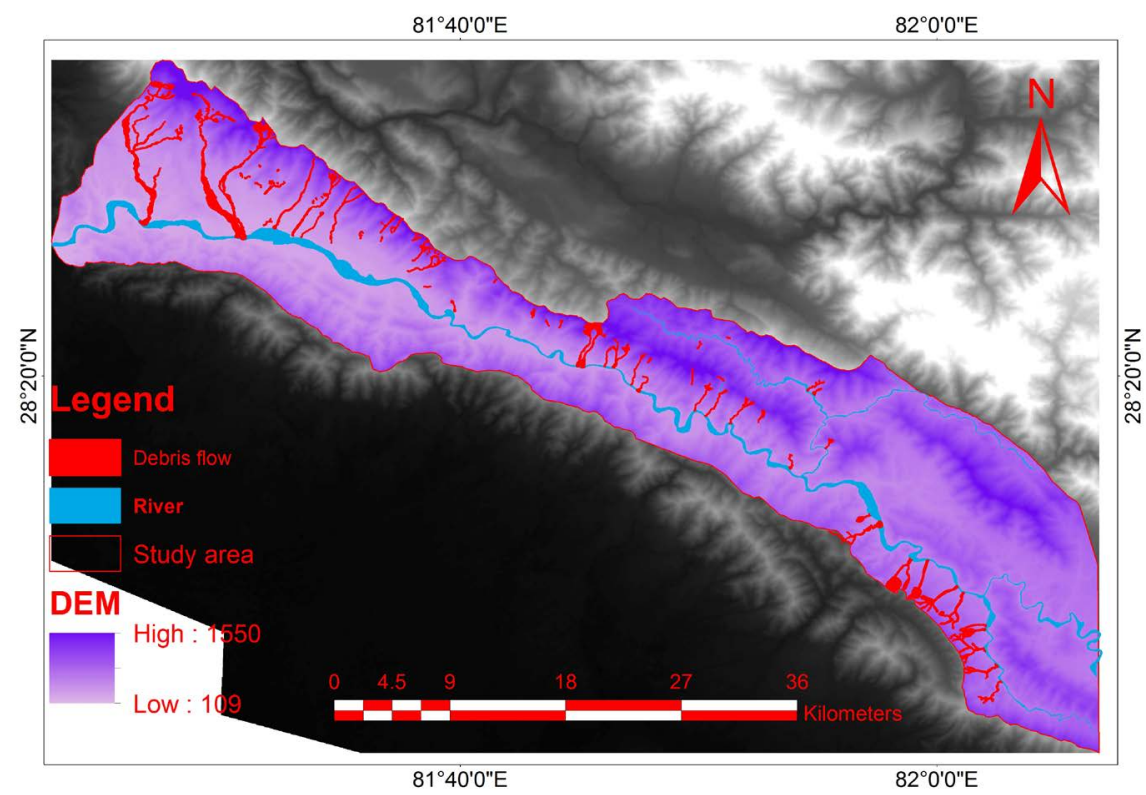

Figure 3. Debris flow inventory of Babai watershed. 


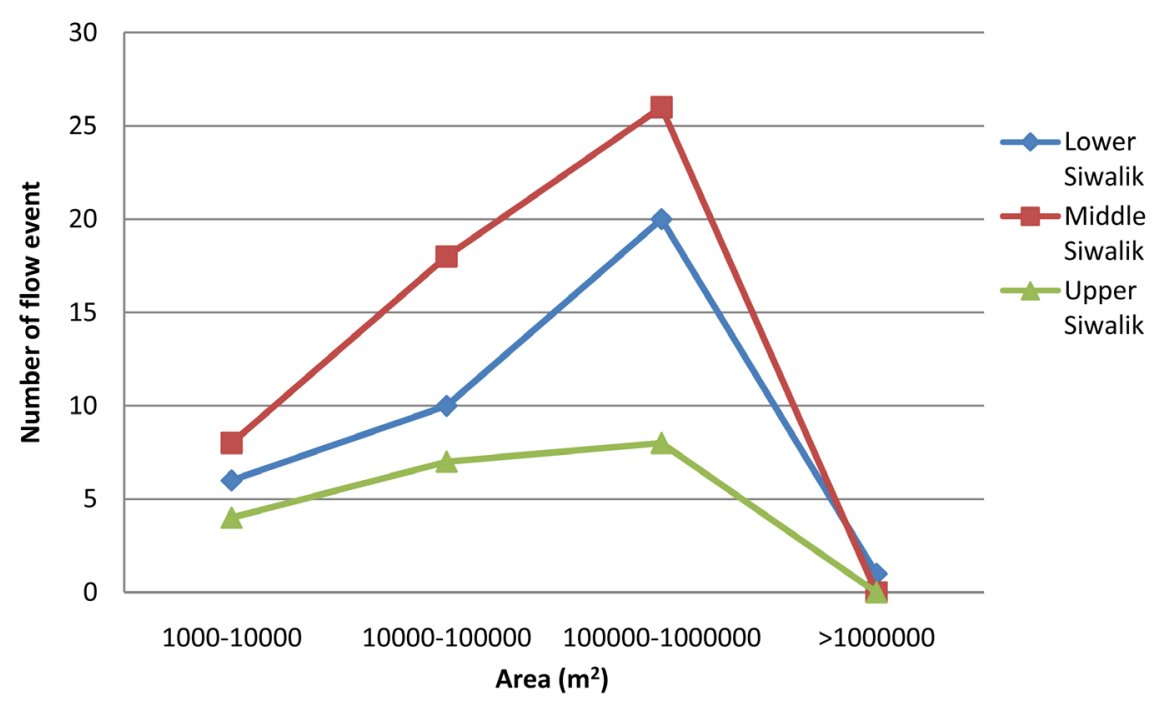

Figure 4. Figure shows the area of debris flow in different geological formation.

Table 1. Total area and number of debris flow in different geological formation.

\begin{tabular}{ccc}
\hline Formation & Sum of Area $\left(\mathrm{km}^{2}\right)$ & No. of flow \\
\hline Lower Siwalik & 4.234 & 24 \\
Middle Siwalik & 12.215 & 38 \\
Upper Siwalik & 2.8 & 29 \\
Grand Total & 19.249 & 101 \\
\hline
\end{tabular}

The result shows that the temporal distribution of debris flow is higher in Middle Siwalik since 2001 to 2018. The debris flow distribution trend is fluctuating since 2000 to 2018. The maximum debris flow events were occurred in 2014 and geologically, in Middle Siwalik (Figure 5). The cumulative frequency of debris flow also shows that Middle Siwalik is highly prone for the occurrence of debris flow in the Babai region (Figure 6).

The result shows that the flow length of debris flow is greater than $1000 \mathrm{~m}$ in Middle Siwalik rocks. Most of the debris flow has exceeded the flow length 1000 $\mathrm{m}$. It indicates that landslides and debris flow originated slope must be steep in Middle Siwalik. It can be concluded that debris flow originated in the steep slope travels longer distance due to rapid flow of debris with high velocity water.

A significant difference $\left(\mathrm{F}_{2,98}=3.331, \mathrm{p}=0.039\right)$ in average length of debris flow was found among three geological formations. Average debris flow length was the highest for Middle Siwalik (MS) $2.03 \mathrm{~km}$, ( $\mathrm{p}=0.0003)$ compared to lower Siwalik (LS) $1.101 \mathrm{~km}$ and Upper Siwalik (US) $1.107 \mathrm{~km}$ (Figure 7).

Similarly, average area of debris flow varied significantly among three formations $\left(\mathrm{F}_{2,98}=5.617, \mathrm{p}=0.004\right)$. Average area of debris flow was significantly higher in Middle Siwalik (average area $=0.33014 \mathrm{~km}^{2}, \mathrm{p}=0.008$ ) compared to Lower Siwalik $0.124 \mathrm{~km}^{2}$ and Upper Siwalik (US, Average area $=0.0933 \mathrm{~km}^{2}$ ). 


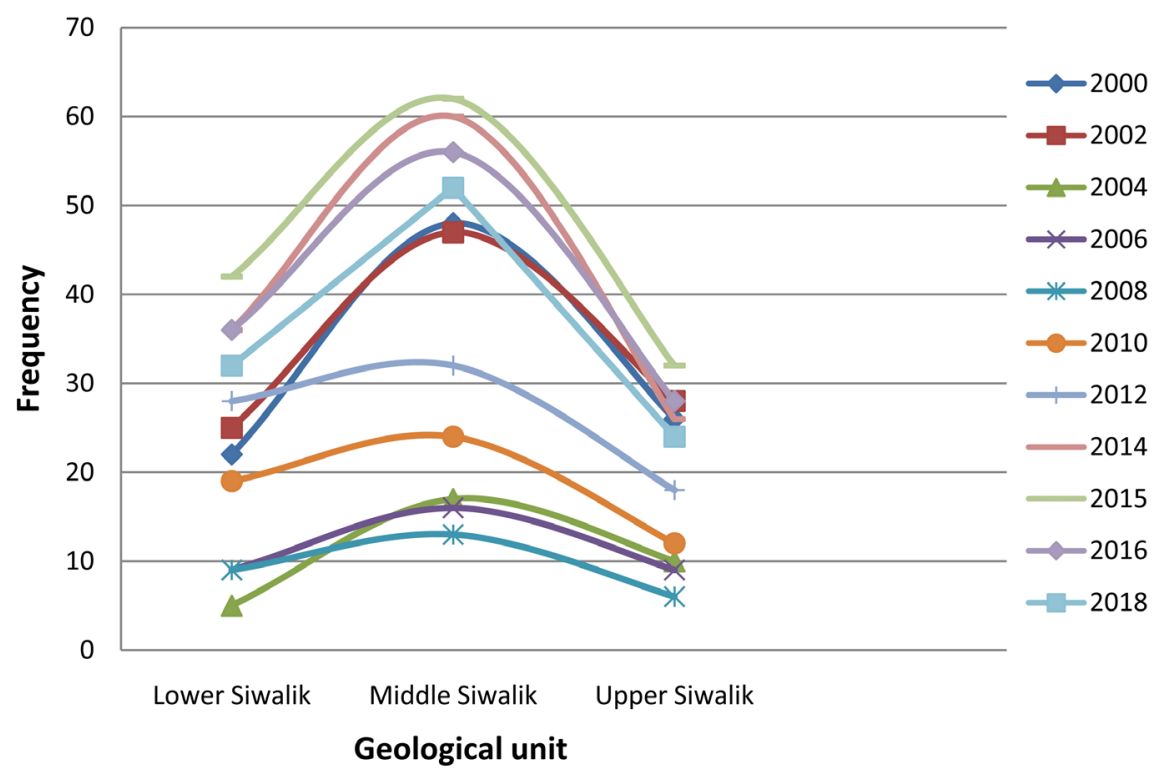

Figure 5. Temporal debris flow frequency in different geological unit.

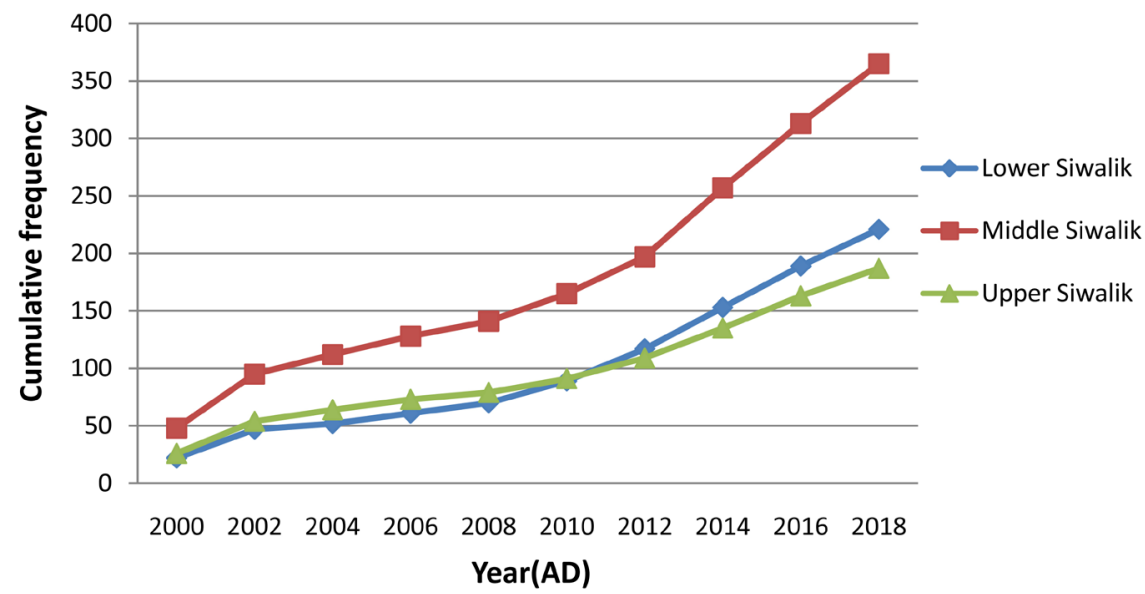

Figure 6. Temporal cumulative frequency of debris flow in different geological unit.
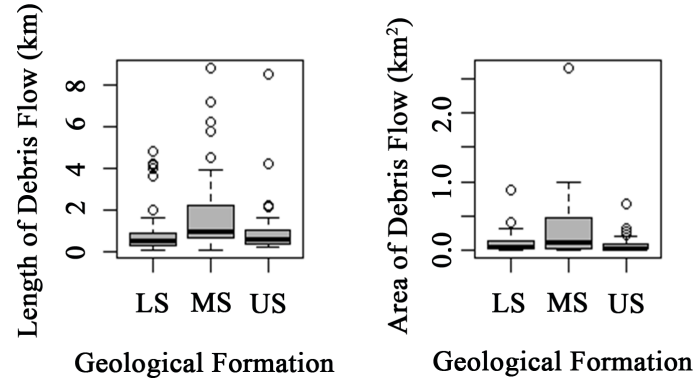

Figure 7. The box plot of Geological formations with length and area of debris flow (LS: Lower Siwalik, MS: Middle Siwalik, US: Upper Siwalik).

\subsubsection{Source of Debris Flow}

The major sources of debris flows are categorized on the basis of five different types of mass movements namely debris slide, rock slide, rock fall, slump and 
gulley erosion. The result shows that debris slides and rock slides are dominant in the Middle Siwalik whereas gulley erosion and debris slides are dominant in Upper Siwalik. Similarly, debris slides and gulley erosions are very common in Lower Siwalik (Figure 8). The result shows that Debris slides are dominant in all geological formations. On the basis of this data, the sources of debris flows are classified into three classes namely fall, slide and erosion. On the basis of origin, the debris flows are classified into three types namely slide induced debris flow, fall induced debris flow and erosion induced debris flow. Generally, the maximum elevation of Lower Siwalik in the study area is $1100 \mathrm{~m}$ whereas the maximum elevation of Middle Siwalik is $1500 \mathrm{~m}$.

\subsubsection{Topographical Distribution}

More than $40 \%$ area of Middle Siwalik has steep slope having inclination greater than $30^{\circ}$ whereas only $15 \%$ area of Lower and Upper Siwalik is greater than $30^{\circ}$. There are topographical differences in different Siwalik hills. Due to that the rock falls and rock slides are common in Middle Siwalik, and the slide/fall induced debris flows are greater in number. Slope of hill is found one of the major causes for debris flow. Figure 9 shows that the landslides are originated in the steep slope and deposit the sediment at the concave slope and valley of different geological unit of Siwalik zone. The deposited materials flow down with the running water during rainfall. The mixture of water and plastic deposits flow down with high speed, and travels long distance to the downhill (Figure 9(B)). Most of the landslides originated at the top of the hills are found converted in to debris flow in every geological formations of Siwalik in the study area. After deep observation of debris channel, it is found that the debris channel is deep, narrow and steep slope $\left(>30^{\circ}\right)$ which caused the sediment to flow easily with gravity in presence of water. In Figure 9 \& Figure 10, landslides deposited huge amount of debris materials at the eroded valley. The valley slope is steep and catchment of most of the valleys is large enough to collect huge amount of water to occur debris flow. From the field it is found that if the slope of valley is greater

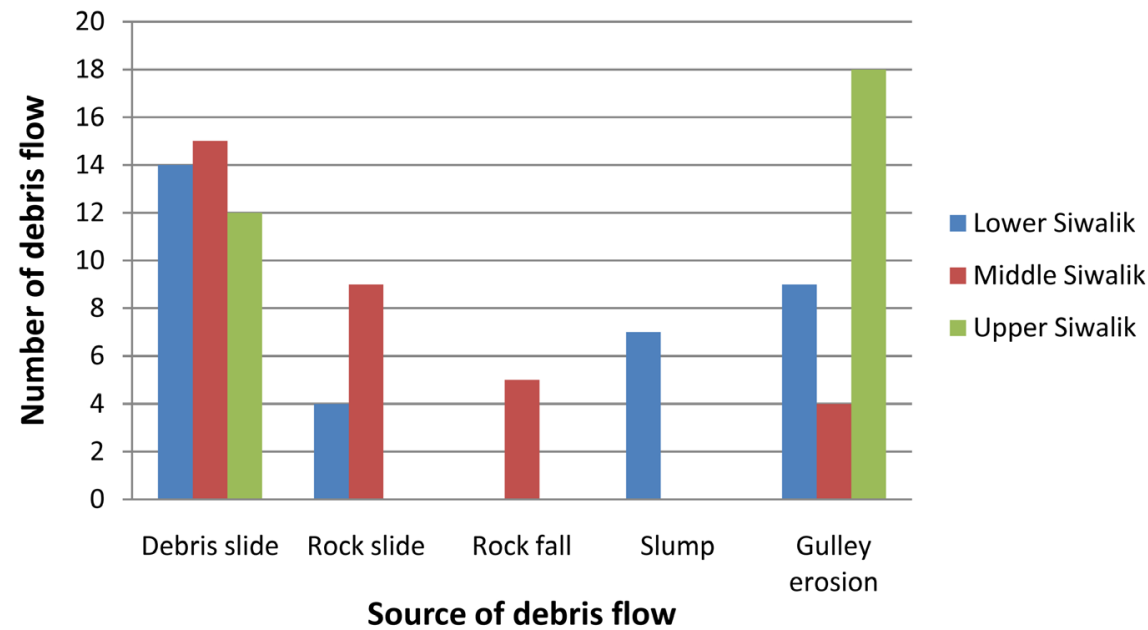

Figure 8. Number of different sources of debris flow in different geological formations. 


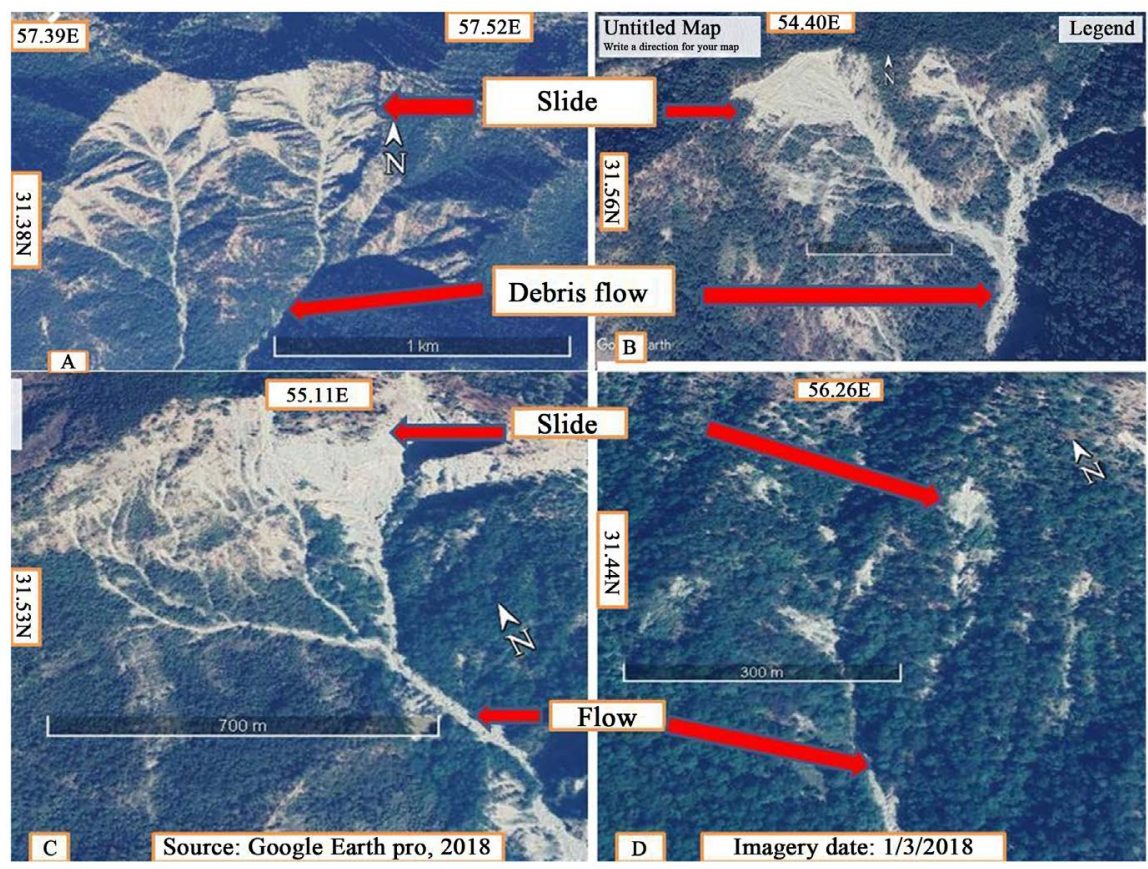

Figure 9. (A) Debris flow occurred after landslide (rock slide) in sandstone bed of Middle Siwalik; (B) Landslide and debris flow occurred in the alternate layer of mudstone and Sandstone of Lower Siwalik; (C) Landslide and debris flow occurred in the contact between Lower and middle Siwalik; (D) Landslide and debris flow occurred in the mudstone of Lower Siwalik.

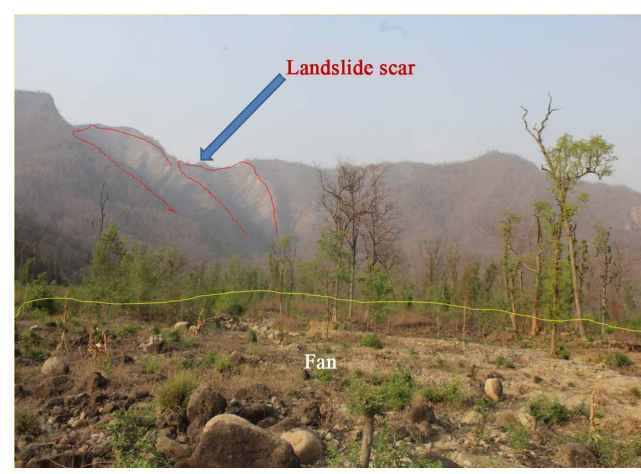

(A)

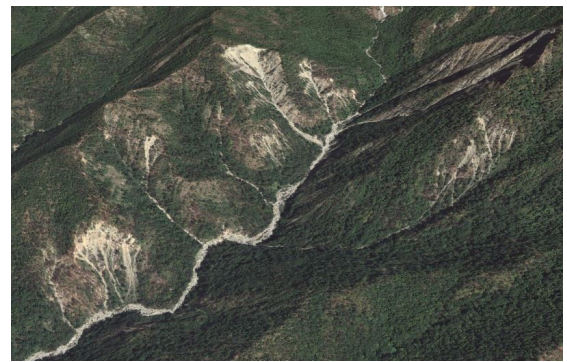

(C)

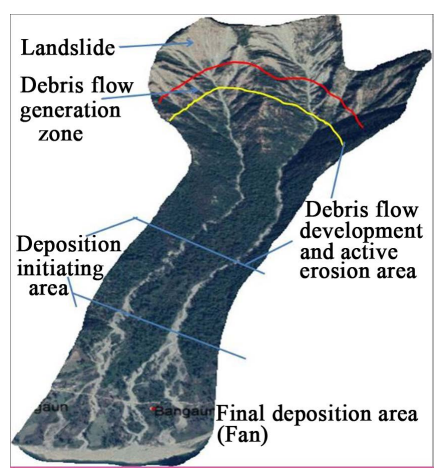

(B)

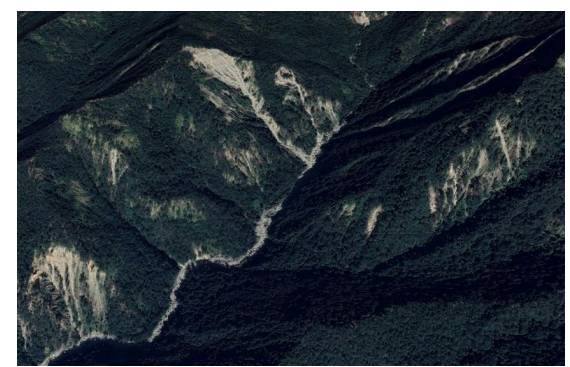

(D)

Figure 10. Landslide induced debris flow. (A) Landslide scar and alluvial fan developed by debris flow; (B) Landslides, debris flow path and deposited fan; (C) Landslides and debris flow occurred in 2016 at Pahire Khola of Bardiya; (D) Landslides and debris flow occurred in 2018 at Pahire Khola Bardiya. 
than $30^{\circ}$ at the landslide toe, there is possibility to occur debris flow during extreme rainfall event. Most of the landslides of slope greater than $30^{\circ}$ are found converted in to debris flow.

After the occurrences of rock fall or rock slide, the rocks are reduced the size because the sedimentary rocks (Sandstone, Mudstone and Conglomerate) are weathered and weakly bonded [18]. Colluviums and talus are made up of differentiated rocky fragments. The rocky fragment becomes the source of debris flow. Due to that the large rock boulder falls are also converted in to debris flow in this region (Figure 11(A) \& Figure 11(B)). This is one of the important mechanisms of debris flow identified in the field. Most of the fluvial sediments and old landslide colluviums erode out in extreme rainfall events. The pebbles, cobbles and mud flow with water in the high speed and travels to the long distance (Figure 11(D)). This type of flow creates after flooding in the stream having steep slope. This type of flow even carries taller tree trunk (Figure 11(C)).

More than $80 \%$ debris flows has been occurred in old debris channel. Increasing the area per year indicates that there is the role of active factors which triggers annually. The landslides having area between $10^{5}-10^{6} \mathrm{~km}^{2}$ having higher frequency every year (Figure 12). It indicates that the large size landslides are very common in this area. The average slope for debris flow occurrence in different geological formations is significantly different. The average slope for debris flow occurrence in Middle Siwalik is $50^{\circ}$ whereas in Lower and Upper Siwaliks are $34^{\circ}$ and $30^{\circ}$ respectively (Figure 13). Since 2000 to 2018, the number of debris flow event has been increasing every year in the different slope. The trend shows that the area of debris flow greater in Middle Siwalik every year. We
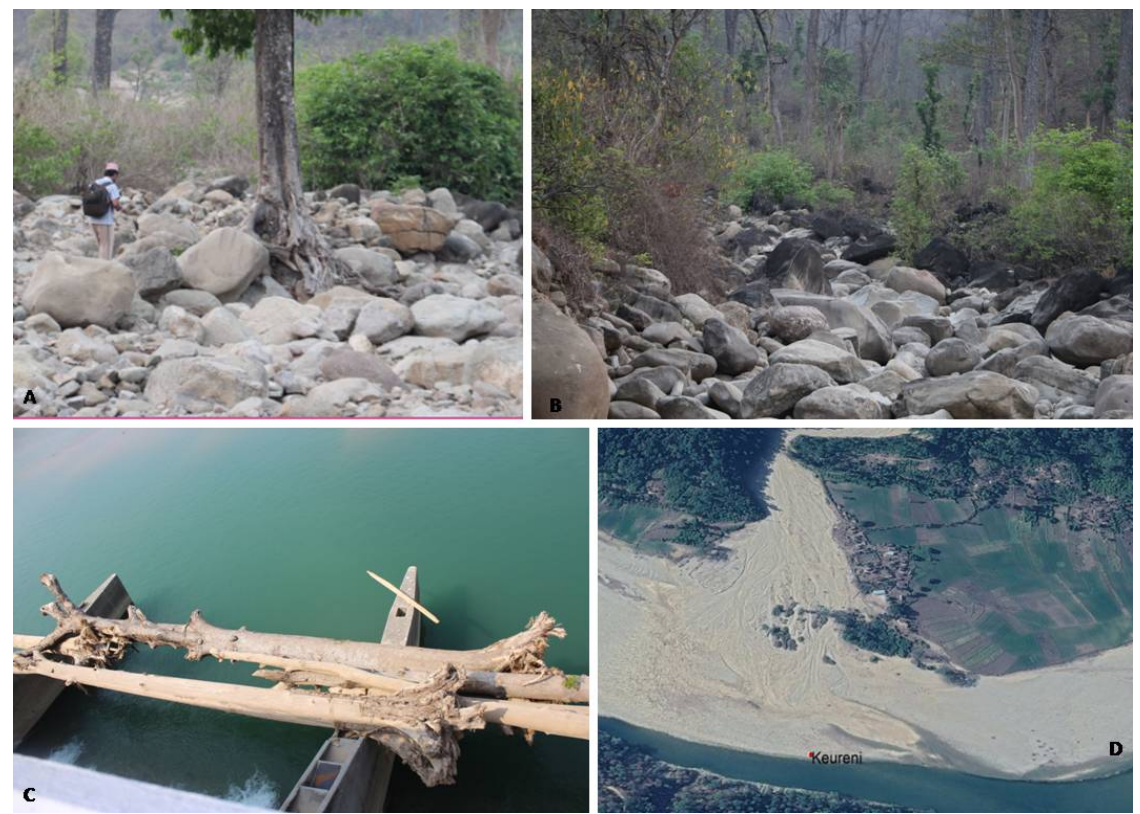

Figure 11. (A) Boulder deposited by 2016 debris in Ban Khola of Salyan; (B) Boulder deposited by 2018 debris flow in Khahare of Salyan; (C) Tree trunk carried by Babai during debris flood in 2018 D. Debris deposited by Keureni Khola of Salyan. 


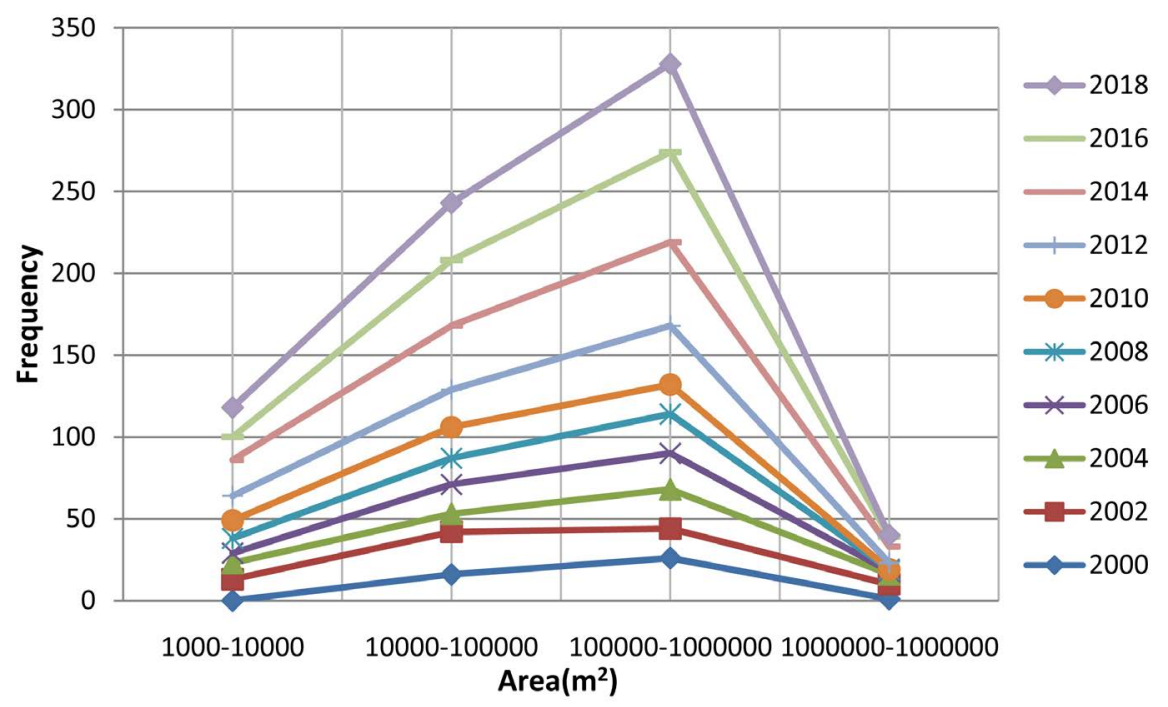

Figure 12. Number of debris flow with different area is given in temporal series.

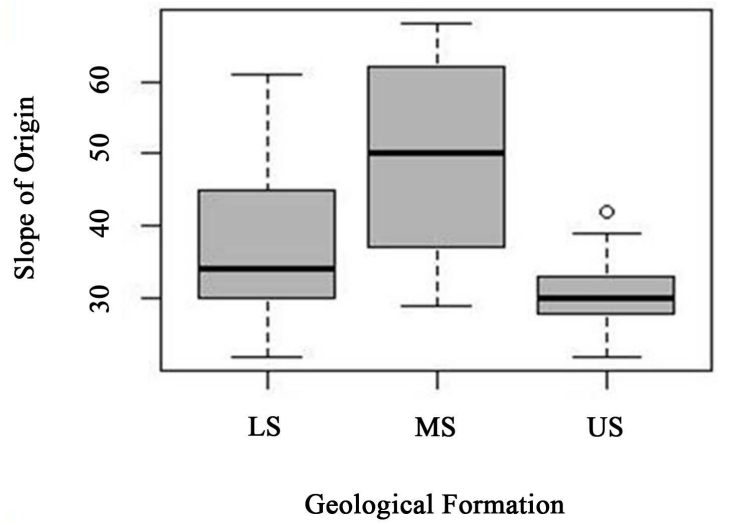

Figure 13. Box plot of geological formation and average slope to occur debris flow (LS: Lower Siwalik, MS: Middle Siwalik, US: Upper Siwalik).

categorized the slope into four categories. The minimum slope is less than $15^{\circ}$ and maximum is greater than $45^{\circ}$. More than $95 \%$ landslides are found above the slope $30^{\circ}$. The trend of debris flow from 2000 to 2018 is shown in Figure 14.

Fall and slide induced debris flows are shown in Figure 15 and Figure 16.

We studied the materials type at the debris deposits. Mostly, the materials were boulder, matrix and cobble/pebble. Types of materials depend on type of debris flow. In Lower Siwalik, it is found that the most of the debris flow consists of cobble, pebble and matrix but in Middle Siwalik, the deposits are boulder, matrix and cobble/pebble. In Upper Siwalik, the deposited materials in most of the debris flows are cobble and pebble.

\subsection{Rainfall and Debris Flow}

The rainfall data of seven stations show that the average annual rain fall of study area varies from $1400 \mathrm{~mm}$ to $3000 \mathrm{~mm}$. The rainfall data of 2000 to 2018 was taken from Department of Hydrology and Meteorology, Government of Nepal 


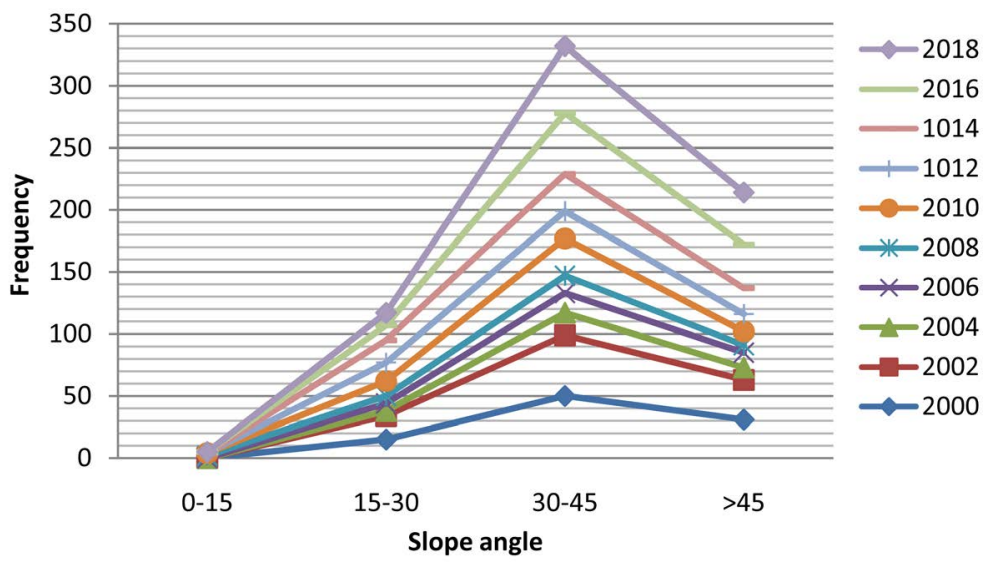

Figure 14. Landslide frequency in different slope angle is given in temporal series.

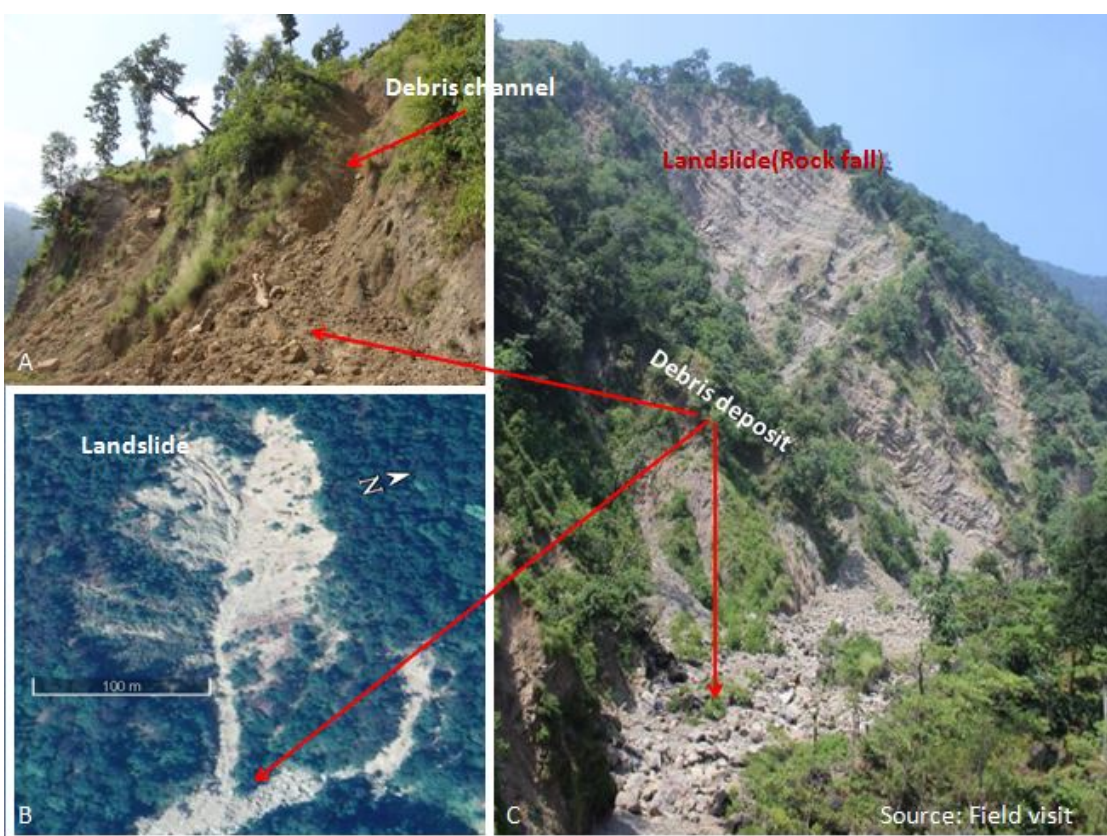

Figure 15. (A), (B) Slide induced debris flow of Lower Siwalik; (C) Fall induced debris flow of Middle Siwalik.

for the analysis of debris flow generation in the study area. The mean annual rainfall of total stations, maximum 24 hours rainfall and number of debris flow events of each year from 2000 to 2017 are analyzed in Figure 17. In 2000, the annual rainfall became $2789.3 \mathrm{~mm}$. Maximum largest landslide induced debris flow had occurred before 1990 but the actual data is lacking. If we see the debris flow events from 2000 to 2018, the highest number of debris flow events has occurred in 2015. In the same year, the maximum 24 hours rainfall was recorded as $236.6 \mathrm{~mm}$ that is the highest rainfall within 24 hours since 2000 . The total rainfall in three months (June, July \& August) in 2015 was $1397.6 \mathrm{~mm}$. Most of the landslide had occurred in the monsoon period of this year. Hence the daily rainfall data of each year and debris flow events of same year are in positive trend (Figure 18). 


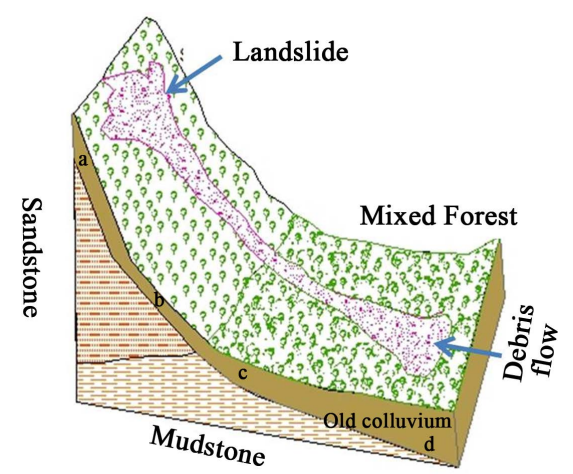

(A)

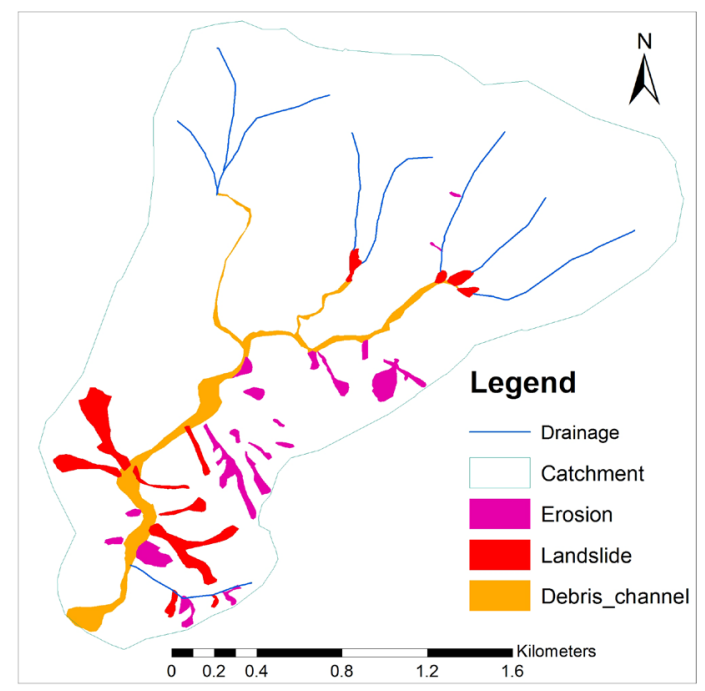

(B)

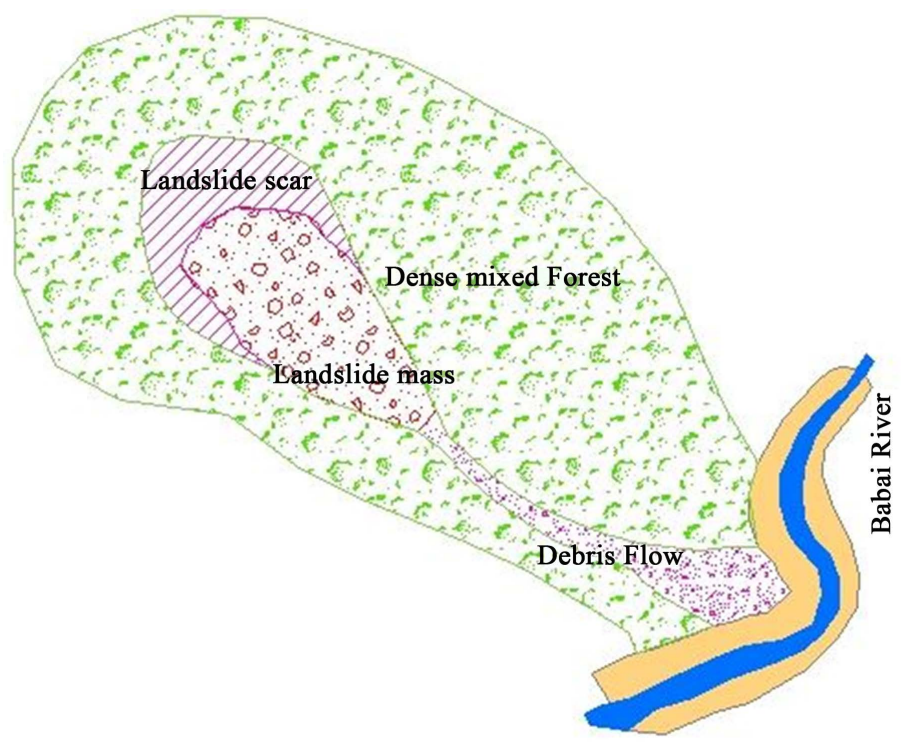

(C)

Figure 16. (A) Model of fall induced debris flow mechanism in Middle Siwalik; (B) Typical debris flow model of the landslide and erosion induced debris flow in Upper Siwalik; (C) Debris flow model of the landslide (slide) induced debris flow in the Lower Siwalik. The drained water carried the landslide mass through the channel. 


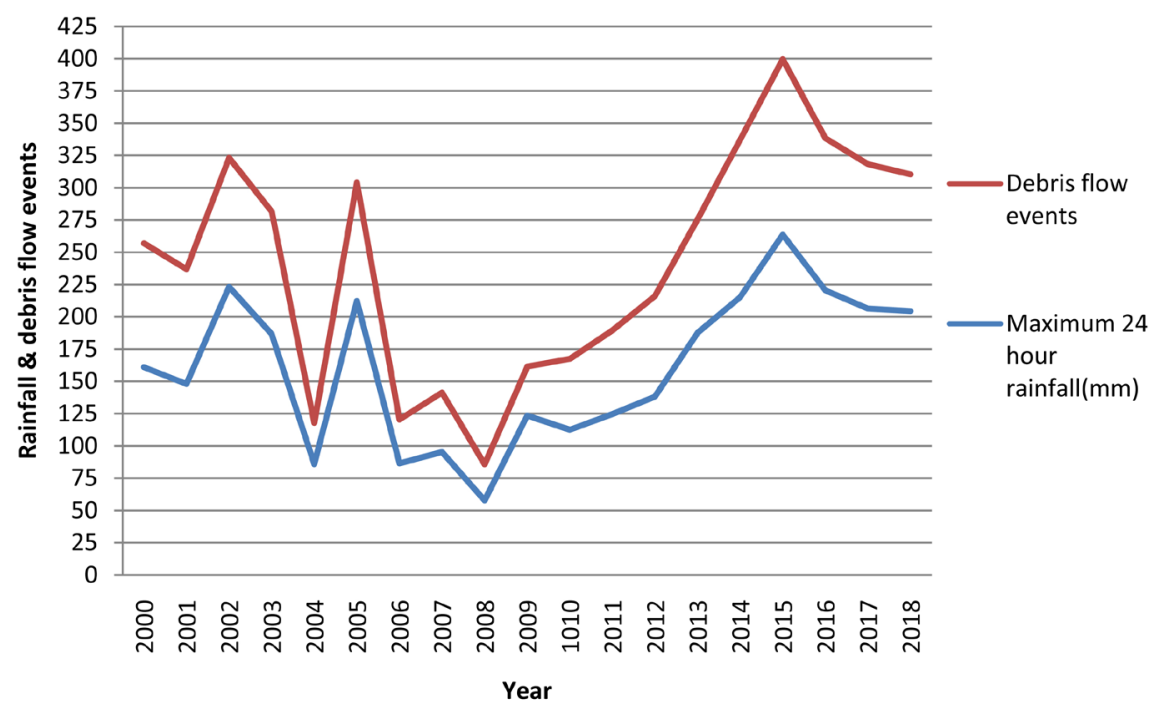

Figure 17. Debris flow and rainfall events of Babai River catchment from 2000 to 2018.

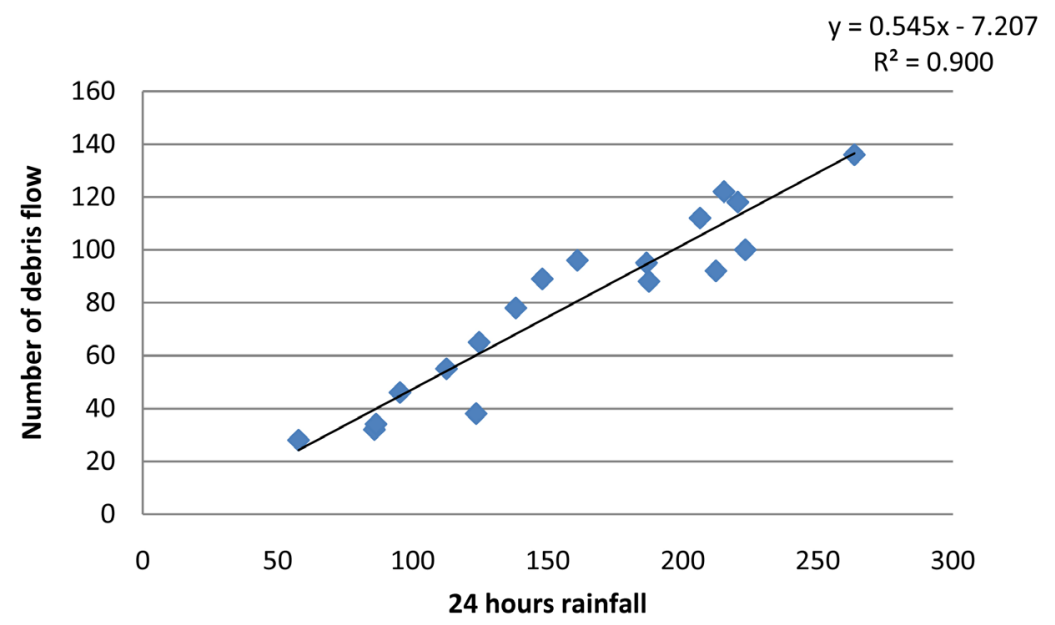

Figure 18. Relation between maximum 24 hrs rainfall and number of debris flow.

From the above result, the rainfall, geology and topography are found major responsible factors for debris flow generation in the study area. As many previous researchers, the Siwalik sediments and bed rocks are found very weak, weathered and fragile. Most of the slope of Siwalik zone are steep and having thick bed rock. In many places, the bed rocks are found covered by colluviums and Quaternary deposit. The weak sedimentary rocks like sandstone, mudstone, shale and conglomerate are easily erodible and most potential for landslides and debris flow. [20] concluded that $20^{\circ}$ slope is enough to generate debris flow from the colluviums deposits. Our result showed that $30^{\circ}$ slope is the critical slope whereas the higher number of debris flow events has occurred in the slope greater than $30^{\circ}$. [3] studied about the debris flow evolution in Japan and concluded that the landslide block transformation is major cause of debris flow. Our result shows that most of debris flows are generated from landslide mass in the slope greater than $30^{\circ}$. [10] studied about the rainfall induced landslide and de- 
bris flow and provided the case of Matatirtha, southern hill of Kathmandu and used the term flow like landslide i.e. the main cause of flow was rain water. Our result also concluded that the heavy rainfall is the major cause for debris flow occurrence including rock type, hill slope and valley. The types of flow are: the debris flow originated from slide, debris flow originated from fall and debris flow originated from erosion. The Middle Siwalik consists of thickly bedded sandstone in steep slope. The present result shows that an average slope to occur debris flow is $50^{\circ}$. The result is justified. Similarly an average slope to occur debris flow in Lower and Upper Siwalik is $34^{\circ}$ and $30^{\circ}$ respectively. Topographically, an average slope of Upper and Lower Siwaliks is less than $40^{\circ}$. The Geology and average slope of debris flow occurrence is justified. According to [18], the major type of landslides in the study area is: Fall, Slide and erosion induced landslide. Thus study shows that the major sources of debris flows are fall, slide and erosion. It justified that the landslide and erosion are major cause and source of debris flow. The result of linear regression between 24 hour rainfall and number of debris flow in temporal series shows that there is good correlation between rainfall and debris flow.

\section{Conclusion}

This paper analyzed the topographical, geological and hydrological information for the generation of debris flow in Siwalik of Babai River watershed, Nepal. The qualitative and quantitative characteristics revealed by rainfall, geology and topography are described. The rock characteristics, slope, topographic features and rainfall have played to generate the debris flow from landslide, erosion and flood in the study area. We found that the slope greater than $30^{\circ}$ is prone to landslide, erosion and debris flow in this area. The landslide mass deposited at the concave slope, stream and valley, eroded materials by flowing water and old colluviums are major sources for debris flow generation. Most of the debris flows are found to occur during the rainfall greater than $200 \mathrm{~mm}$ within 24 hours. The slope greater than $30^{\circ}$ produces high runoff rates during rainfall. However, the debris flow mechanisms are differing in different geological formations. Landslide induced debris flows are dominant in the sandstone beds whereas, erosion induced landslides are dominant in mudstone, conglomerate beds and colluviums deposits. Among the geological formations, Middle Siwalik is found as more sensitive for the occurrence of debris flow. The result shows the interrelationship between, topography, geology, rainfall and debris flow in the Siwalik of Babai catchment. Geotechnical characteristics and mathematical modeling have not been included in this paper. The authors recommend the geotechnical study of debris materials to identify the detail information of debris flow. Debris flow hazard modeling may be the next research in this area.

\section{Acknowledgements}

We acknowledge the help of people lives in Babai valley and Nepal army of Bar- 
dia National Park for their valuable support during field work. Nepal army provided permission and security for the field work inside the dense forest of $\mathrm{Na}$ tional park.

\section{Data Availability}

The Google images were found freely from the free online Google earth image. The references were found from Google Scholar. Topographical maps of study area were found from the Department of Survey, Government of Nepal.

\section{Conflicts of Interest}

The authors declare no conflicts of interest regarding the publication of this paper.

\section{References}

[1] Hungr, O., Leroueil, S. and Picarelli, L. (2014) The Varnes Classification of Landslide Types, an Update. Landslides, 11, 167-194.

https://doi.org/10.1007/s10346-013-0436-y

[2] Nomitsu, R. and Seno, K. (1959) New Potamology. Chijin Shokan, Tokyo, 1-318. (In Japanese)

[3] Tani, T. (1968) On Debris Flow (Yamatsunami). Water Science, 60, 106-126. (In Japanese)

[4] Revellino, P., Hungr, O., Guadagno, F.M. and Evans, S.G. (2004) Velocity and Runout Simulation of Destructive Debris Flows and Debris Avalanches in Pyroclastic Deposits, Campania Region, Italy. Environmental Geology, 45, 295-311. https://doi.org/10.1007/s00254-003-0885-Z

[5] Grelle, G., Revellino, P., Donnarumma, A. and Guadagno, F.M. (2011) Bedding Control on Landslides: A Methodological Approach for Computer-Aided Mapping Analysis. Natural Hazards Earth System Science, 11, 1395-1409. https://doi.org/10.5194/nhess-11-1395-2011

[6] Rickenmann, D. and Zimmermann, M. (1993) The 1987 Debris Flows in Switzerland: Documentation and Analysis. Geomorphology, 8, 175-189. https://doi.org/10.1016/0169-555X(93)90036-2

[7] Hungr, O., Morgan, G.C. and Krllerhals, R. (1984) Quantitative Analysis of Debris Torrent Hazard for Design of Remedial Measures. Canadian Geotechnical Journal, 21, 663-667. https://doi.org/10.1139/t84-073

[8] Takahashi, T. (1981) Estimation of Potential Debris Flow and Their Hazardous Zone. Soft Counter Measure for a Disaster. Journal of Natural Disaster Science, 3, 57-89.

[9] Searle, M.P., Windley, B., Coward, M., Cooper, D., Rex, A., Rex, D., Tingdong, L., Xuchang, X., Jan, M., Thakur, V. and Kumar, S. (1987) The Closing of Tethys and the Tectonics of the Himalaya. Geological Society of America Bulletin, 98, 678-701. https://doi.org/10.1130/0016-7606(1987)98<678:TCOTAT>2.0.CO;2

[10] Dahal, R.K., Hasegawa, S., Yamanaka, M. and Nishino, K. (2006) Rainfall Triggered Flow-Like Landslides: Understanding from Southern Hills of Kathmandu, Nepal and Northern Shikoku, Japan. Proceedings of 10 th International Congress of IAEG, The Geological Society of London, IAEG2006 Paper No. 819, 1-14. 
[11] Dahal, R.K., Hasegawa, S., Bhandary, N.P. and Yatabe, R. (2010) Low-Cost Road for the Development of Nepal and Its Engineering Geological Consequences. Geologically Active, Proceedings of the 11 th IAEG Congress, 5, 4085-4094.

[12] Cui, Z.-K., Bastiat, G. and Lafleur, M. (2010) Formation of Fluid Lamellar Phase and Large Unilamellar Vesicles with Octadecyl Methyl Sulfoxide/Cholesterol Mixture. Langmuir, 26, 12733-12739. https://doi.org/10.1021/la100749k

[13] Bhandari, B.P. and Dhakal, S. (2019) Topographical and Geological Factors on Gulley Type Debris Flow in Malai River Catchment, Siwaliks, Nepal. Journal of Nepal Geological Society, 59, 89-94. https://doi.org/10.3126/jngs.v59i0.24994

[14] Kim, D.E., Seong, Y.B., Choi, K.H. and Yu, B.Y. (2017) Role of Debris Flow on the Change of ${ }^{10} \mathrm{Be}$ Concentration in Rapidly Eroding Watersheds: A Case Study on the Seti River, Central Nepal. Journal of Mountain Science, 14, 716-730. https://doi.org/10.1007/s11629-016-4282-y

[15] Khanal, N. and Watanable, T. (2008) Landslide and Debris Flow in the Himalaya, A Case Study of the Madi Watershed of Nepal. Himalayan Journal of Sciences, 2, 180-181. https://doi.org/10.3126/hjs.v2i4.864

[16] Adhikary, D.P. and Koshimizu, S. (2005) Debris Flow Disaster at Larcha, Upper Bhotekosi Valley, Central Nepal. Islander Arc, 14, 410-423. https://doi.org/10.1111/j.1440-1738.2005.00495.x

[17] Bhandary, N.P., Dahal, R.K. and Okamura, M. (2012) Preliminary Understanding of the Seti River Debris-Flood in Pokhara, Nepal, on May 5th, 2012, A Report Based on a Quick Field Visit Program. International Society of Soil Mechanics and Geotechnical Engineering Bulletin, 6, 8-18.

[18] Bhandari, B.P. and Dhakal, S. (2018) Lithological Control on Landslide in the Babai Khola Watershed, Siwaliks Zone of Nepal. American Journal of Earth Sciences, 5, 54-64.

[19] Hagen, T. (1969) Report on the Geological Survey on Nepal. V.1. Denkschrift. Schweizerische Naturforschende Gesellschaft, 86, 1-185.

[20] Daido, A. (1971) On the Occurrence of Mud-Debris Flow. Bulletin of the Disaster Prevention Research Institute, 21, 109-135. 